EESTI NSV TEADUSTE AKADEEMIA TOIMETISED, 24, KOIDE KEEMIA * GEOLOOGIA. 1975, NR. 4

ИЗВЕСТИЯ АКАДЕМИИ НАУК ЭСТОНСКОИ ССР. ТОМ 24 ХИМИЯ * ГЕОЛОГИЯ, 1975, № 4

удК $547.361+547.913+668.5$

T. КААЛ, К. ЛЭЭТС

\title{
ТЕРПЕНОВЫЕ СПИРТЫ И АЦЕТАТЫ ИЗ ПРОДУКТА ТЕЛОМЕРИЗАЦИИ ИЗОПРЕНА С ЕГО ГИДРОХЛОРИДАМИ
}

В настоящей работе исследовались методы разделения продукта омыления терпеновых хлоридов, полученных теломеризацией изопрена с его гидрохлоридами и остающихся в смеси после удаления геранилхлорида в виде комплекса с гексаметилентетрамином [']. Состав смеси хлоридов определен ранее омылением отдельных фракций хлоридов $\left[{ }^{2,3}\right]$, а также прямым анализом с помощью газожидкостной хроматографии $(\Gamma Ж X)[4]$.

Рис. 1. Хроматограмма продукта омыления терпеновых хлоридов. 1 и 2 - терпеновые углеводороды, 3 лавандулилхлорид, 4 - линалоол, $5-2,7$-диметилоктадиен-1,6-ол-3, $6-\alpha$-терпинеол, $7-2,7$-диметилоктадиен-2,6-ол-1, 8 - гидрат лавандулилхлорида.

«Хром-1», колонка 5 м, Ø 4,5 мм, заполненная $3 \%$ полиэфира адипиновой кислоты и этиленгликоля на хромосорбе $W$ (30-60 меш), рабочая температура $160^{\circ}$, газ-носитель - аргон.

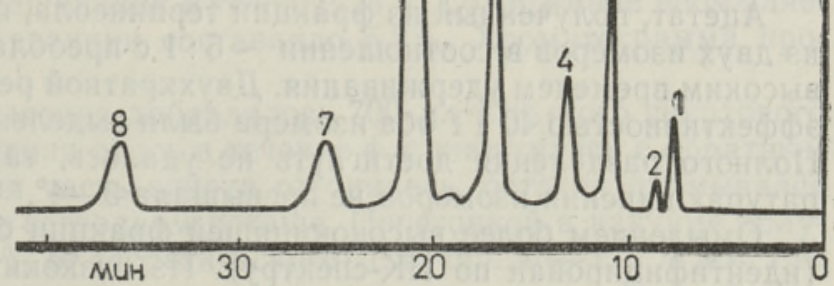

Смесь терпеновых хлоридов омылялась $5 \%$-ным водным раствором бикарбоната натрия при $90^{\circ} \mathrm{C}$, причем часть хлоридов, по данным ГЖХ (рис. 1), оставалась неомыленной, что наблюдалось и в предыдущих исследованиях $[2,4,5]$. Сюда относятся лавандулилхлорид и димер гидрохлорида изопрена. В последнем омыляется третичный атом хлора с образованием гидрата лавандулилхлорида (2.6-диметил-3-хлорметилгептен-5-ола-2) [5]. Это соединение при разгонке продукта частично разлагается. Выделяющийся $\mathrm{HCl}$ приводит к дегидратации спиртов. Поэтому оказалось необходимым дегидрохлорирование продукта омыления спиртовым раствором КОН. Лавандулилхлорид и его гидрат при этом превращаются в углеводороды. 
Характеристика исходной смеси и полученных продуктов

\begin{tabular}{|c|c|c|c|c|c|c|}
\hline Вещество & \begin{tabular}{|} 
Удельное \\
зремя удер- \\
живания \\
$(\alpha$-терпи- \\
неол-1)
\end{tabular} & $\begin{array}{c}\text { Содержание в сме- } \\
\text { си до и после де- } \\
\text { гидрохлориро- } \\
\text { вания, \% }\end{array}$ & $\begin{array}{l}\text { T. кип. } \\
\text { при } \\
15 \text { мм } \\
\text { рт. } c т . \\
{ }_{\mathrm{C}}\end{array}$ & $d_{4}^{20}$ & $n_{D}^{20}$ & $\begin{array}{c}\text { Чистота, } \\
\% \text { по } \\
\text { данным } \\
\text { ГЖХ }\end{array}$ \\
\hline
\end{tabular}

Терпеновые углеводо. роды

Лавандулилхлорид

Линалоол

Изолиналоол

$\boldsymbol{\alpha}$-Терпинеол

м-Ментен-6-ол-8

Изогераниол

Гидрат лавандулилхлорида

Изолиналилацетат

$\boldsymbol{\alpha}$-Терпинилацетат

Ацетат м-ментен-

6-ола-8

Изогеранилацетат

\begin{tabular}{|c|c|c|c|c|c|}
\hline $\begin{array}{c}0,2-0,37 \\
0,40 \\
0,55 \\
0,76 \\
1,00 \\
1,00 \\
1,24\end{array}$ & $\begin{array}{r}7,1 \\
9,2 \\
8,2 \\
16,4 \\
44,3 \\
\vdots \\
6,8\end{array}$ & $\begin{array}{r}25,8 \\
1,2 \\
7,7 \\
16,9 \\
41,4 \\
: \\
7,0\end{array}$ & $\begin{array}{c}60-82 \\
- \\
89-92 \\
100-101 \\
106-107 \\
77-78 / 5 \\
112-113\end{array}$ & $\begin{array}{c}\overline{\bar{T}} \\
0, \overline{8641} \\
0,8821 \\
0,9324 \\
0,9397 \\
0,8839\end{array}$ & $\begin{array}{l}\overline{-} \\
1,4660 \\
1,4711 \\
1,4821 \\
1,4838 \\
1,4757 .\end{array}$ \\
\hline $\begin{array}{l}1,86 \\
0,73 \\
1,08\end{array}$ & $\frac{8,0}{-}$ & $\bar{z}$ & $\begin{array}{c}106-107 \\
116\end{array}$ & $\begin{array}{l}\overline{-} \overline{9048} \\
0,9610\end{array}$ & $\begin{array}{l}\overline{4512} \\
1,4669\end{array}$ \\
\hline $\begin{array}{l}1,00 \\
1,13\end{array}$ & - & - & $\begin{array}{c}112 \\
120-121\end{array}$ & $\begin{array}{l}0,9614 \\
0,9132\end{array}$ & $\begin{array}{l}1,4671 \\
1,4632\end{array}$ \\
\hline
\end{tabular}

- В таблице дано суммарное содержание $\alpha$-терпинеола в $\boldsymbol{\kappa - м е н т е н - 6 - о л а - 8 . ~}$

Полученная смесь терпеновых спиртов и углеводородов ректифицировалась в вакууме. Было выделено четыре фракции, соответствующих следующим спиртам: линалоолу, 2,7-диметилоктадиен-1,6-олу-3 (изолиналоолу), $\alpha$-терпинеолу и 2,7-диметилоктадиен-2,6-олу-1 (изогераниолу). Терпинеол и линалоол, выделенные также в работе [ $\left.{ }^{2}\right]$, идентифицировались по ИК-спектрам; два остальных спирта, по данным ГЖХ и физическим константам, оказались идентичными с полученными ранее образцами изолиналоола и изогераниола [3,6]. Структура последних доказана с помощью спектров ЯМР.

Из выделенных спиртов были получены также ацетаты, характеристика которых приведена в таблице.

Ацетат, полученный из фракции терпинеола, по данным ГЖХ, состоял из двух изомеров в соотношении $\sim 5: 1$ с преобладанием изомера с более высоким временем удерживания. Двухкратной ректификацией на колонке эффективностью 40 ТТ оба изомера были выделены с чистотой около $85 \%$. Полного разделения достигнуть не удалось, так как разница в темпе ратурах кипения изомеров не превышала $3-4^{\circ}$.

Омылением более высококипящей фракции был получен $\alpha$-терпинеол (идентифицирован по ИК-спектру). Из низкокипящей фракции получен терпеновый спирт, мало отличающийся от $\alpha$-терпинеола по физическим константам. ИК-спектр выделенного спирта (рис. 2,a) дает основание приписывать ему строение $м$-ментен-6-ола-8 (1-метил-3-гидроксиизопропилциклогексена-1). Этот спирт недавно получен в чистом виде и охарактеризован И. Бардышевым с сотрудниками [7].

Из м-ментен-6-ола-8 при помощи $\mathrm{PCl}_{5}$ был получен хлорид (с примесью терпенов), имеющий при ГЖХ время удерживания 0,57 по отношению к геранилхлориду. Такая же величина характерна для одного компонента фракции терпеновых хлоридов теломера изопрена с его гидрохлоридами ( $\alpha$-терпинилхлорид имеет время удерживания 0,63$)\left[{ }^{4}\right]$. Из этого можно заключить, что при теломеризации, кроме ранее идентифицированных соединений, образуется также циклический продукт 4,1-присоединения гидрохлорида изопрена к изопрену. 

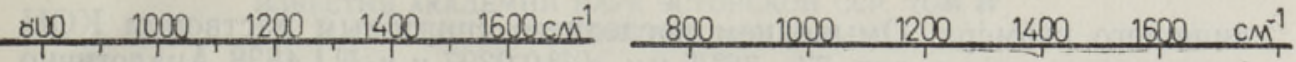

a

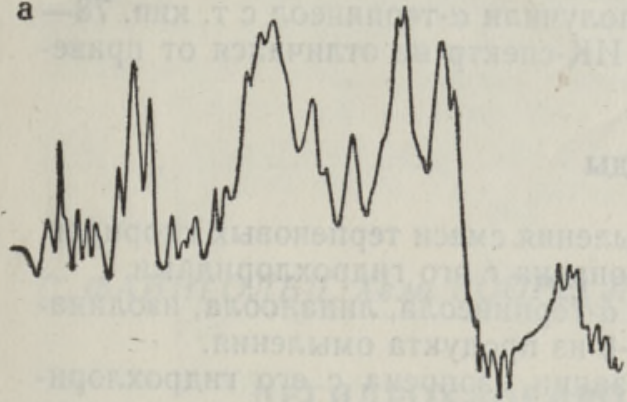

$\delta$

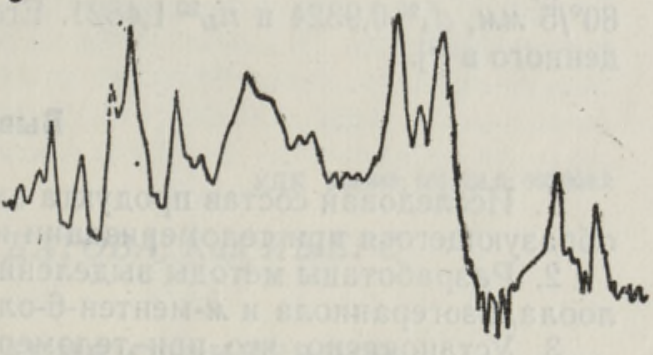

Рис. 2. Инфракрасные спектры м-ментен-6-ола-8 (a) и линалоола (б), полученные на приборе UR-10. Максимум поглощения, показанный пунктиром, отсутствует в спектре чистого линалоола.

Фракция, соответствующая линалоолу, по данным ИК-спектроскопии (рис. $2, \sigma)$, содержит также изомерный спирт с метиленовой двойной связыю (максимум поглощения при $890 \mathrm{~cm}^{-1}$ ). Этот изомер, по всей вероятности, имеет структуру 2,6 -диметил-3-метиленгептен-5-ола-2, который в некотором количестве образуется при дегидрохлорировании гидрата лавандулилхлорида; преимущественно образуется соответствующий терпеновый углеводород. Названный изомер линалоола, по литературным данным [8], имеет практически одинаковые с ним физические свойства, чем объясняется также невозможность разделения этих спиртов с помощью ГЖХ или ректификации.

\section{Экспериментальная часть}

1. Омыление и дегидрохлорирование терпеновых хлоридов. Фракция терпеновых хлоридов теломера $\left(d_{4}{ }^{20} 0,9168\right.$ и $\left.n_{D}{ }^{20} 1,4773\right)$ омылялась $5 \%$-ным водным раствором бикарбоната натрия (2-кратный избыток) при $90^{\circ}$ и интенсивном перемешивании в течение 24 и. Содержание неомыляемого хлора в продукте реакщии составляло $5,2 \%$. Хроматограмма продукта приведена на рис. 1.

К 372 г продукта омыления добавлялось 700 мл 10\%-ного спиртового раствора КОН. Реакционная смесь в течение 4 थ кипятилась с обратным холодильником. Бо́льшая часть спирта отгонялась, остаток промывался водой и высушивался на безводном поташе. Перегонкой в вакууме получили 298 г продукта ( $85 \%$ от теоретического) с т. кип. $45-110^{\circ} / 8$ мм. Его состав приведен в таблице.

2. Получение индивидуальных терпеновых спиртов и ацетатов. 163 г продукта дегидрохлорирования разгонялось при 15 мм рт. ст. на колонке эффективностью 40 ТТ со стеклянной насадкой. Характеристика фракций, соответствующих отдельным спиртам, дана в таблице.

Ацетаты терпеновых спиртов получались ацетилированием выделенных ректификацией спиртов уксусным ангидридом при непрерывной отгонке образующейся уксусной кислоты в виде азеотропа с толуолом [ $\left.{ }^{9}\right]$. Ректификация ацетата, полученного из фракции терпинеола, проводилась на вышеупомянутой колонке при флегмовом числе 30-40. Фракция с т. кип. $116-118^{\circ} / 17$ мм, содержащая, по данным ГЖХ, около $40 \%$ изомера, имеющего т. кип. ниже, чем у $\alpha$-терпинилацетата, ректифицировалась вторично. Полученная фракция с т. кип. $112^{\circ} / 15$ мм содержала $85 \%$ низко- 
кипящего изомера. Омылением последнего спиртовым раствором КОН получили спирт с т. кип. $77-78^{\circ} / 5 \mu \mu, d_{4}{ }^{20} 0,9397$ и $n_{D}{ }^{20} 1,4838$. Аналогично из фракции с т. кип. 115-116\%15 мм получили $\alpha$-терпинеол с т. кип. $78-$ $80^{\circ} / 5$ мм, $d_{4}{ }^{20} 0,9324$ и $n_{D}{ }^{20} 1,4821$. Его ИК-спектр не отличался от приведенного в [6].

\section{Выводы}

1. Исследован состав продукта омыления смеси терпеновых хлоридов, образующегося при теломеризации изопрена с его гидрохлоридами.

2. Разработаны методы выделения $\alpha$-терпинеола, линалоола, изолиналоола, изогераниола и $M$-ментен-6-ола-8 из продукта омыления.

3. Установлено, что при теломеризации изопрена с его гидрохлоридами, кроме ранее идентифицированных соединений, образуется также циклический продукт 4,1-присоединения - 1-метил-3-хлоризопропилциклогексен-1.

\section{ЛИТЕРАТ У РА}

1. Лээтс К. В., Шумейко А. К., Розеноер А. А., Кудряшова И. В., Пи ля в ск ая А. И., ЖОХ, 27, 1510 (1957).

2. Л э э т С K. В., ЖОХ, 28, 3096 (1958).

3. Л ээт С К., Ка ал Т., Юрьен с Х,, Изв. АН ЭССР, Хим. Геол., 17, 429 (1968).

4. Л ээтс К., Каал Т., Калья И., Кудрявцев И., Мукс Э., Тали М., Тенг С., Э р м Ӓ., Изв. АН ЭССР, Хим. Геол., 21, 305 (1972),

5. К а а л Т., Л ээ т с К., Изв. АН ЭССР, Хим. Геол., 21, 269 (1972).

6. Эр м А., Л э э т с К., Изв, АН ЭССР, Хим. Геол., 16, 37 (1967).

7. Бардышев И. И., ГорбачеваИ. В., Перцовский А. Л., Изв. АН БССР, Сер. хим. наук, 47, (1969).

8. Schinz H., B ourqui n J.P., Helv. Chim. Acta, 25, 1592 (1942).

9. A e s ch b a ch M. Е., пат. США № 2423545 (1947).

$\begin{array}{cc}\text { Ннститут химии } & \text { Поступнла в редакцию } \\ \text { Академии наук Эстонской ССР } & 11 / \mathrm{XI} 1973\end{array}$

T. KAAL, K. LAATS

\section{ISOPREENI JA TEMA HODROKLORIIDIDE TELOMEERIST SAADUD TERPEENALKOHOLID JA ATSETAADID}

Uuriti terpeenalkoholide segude eraldamise meetodeid. Isopreeni ja tema hüdrokloriidide telomerisatsioonil saadud terpeenkloriidide segu seebistati ja reageerimata kloriidid dehüdrokloreeriti alkohoolse kaaliumhüdroksüüdiga. Saadud produkti rektifitseerimisel eraldati järgmised terpeenalkoholid: linalool, 2,7-dimetüüloktadieen-1,6-ool-3, 2,7-dimetüüloktadieen-2,6-ool-1 ning $\alpha$-terpineooli ja m-menteen-6-ool-8 segu. Viimane lahutati vastavate atsetaatide rektifitseerimisel.

\section{T. KAAL, K. LAĂTS}

\section{TERPENIC ALCOHOLS AND ACETATES FROM THE TELOMERIZATION PRODUCT OF ISOPRENE WITH ITS HYDROCHLORIDES}

The methods of separation of the mixtures of terpenic alcohols were investigated. The mixture of terpenic chlorides prepared by telomerization of isoprene with its hydrochlorides was saponified and the nonreacted chlorides dehydrochlorinated with alcoholic potassium hydroxide. By means of rectification, terpenic alcohols were isolated as follows: linalool, 2,7-dimethyl-1,6-octadien-3-ol, 2,7-dimethyl-2,6-octadien-1-ol and the mixture of $\alpha$-terpineol and $\mathrm{m}-6$-menthene-8-ol. These alcohols were separated by rectification of the corresponding acetates. 